\title{
Effect of Fortification of Goat Meat Products with Flaxseed Powder on the Lipid Profile, Livers and Kidneys Functions of Male Albino Rats
}

Youssef, M.K.E. ${ }^{1}$; A.R. Ahmed ${ }^{2}$; Iryani W. Basta ${ }^{2}$; A.M.A. Abd- El-Reheem ${ }^{3}$ and Laila M. S. Salim ${ }^{2}$

\author{
${ }^{1}$ Food Science \& Technology Department, Fac. of Agric., Assiut Univ. \\ ${ }^{2}$ Home Economic Department - Fac of Spec. Education Ain-Shams Univ. \\ ${ }^{3}$ Zoology Department - Fac. of Sci., Al-Azhar Univ., Assiut Branch. \\ Received on: $23 / 8 / 2016$ \\ Accepted for publication on: 5/10/2016
}

\begin{abstract}
This study was undertaken to determine the effect of flaxseed powder and goat meat products fortified with flaxseed powder on the quantity of liver enzymes, lipid fraction and kidney function of rats suffering from hyperlipidemia. Two main experimental groups used in this experiment. The first group (6 rats) fed on basal diet as a control negative, while the second one (54 rats) was treated with cholesterol in cholic acid (2:1 2.1 gm/group) to arise hyperlipidemia levels of experimental animals. Then, the second main group was divided into nine subgroups. Subgroup (1) (6 rats) fed on basal diet as positive control group. Subgroups (2 and 3 ) fed on diet containing $10 \%$ and $20 \%$ row goat meat, respectively. Subgroups (4 and 5) fed on diet containing 10\% and 20\% flaxseed powder, respectively. Subgroups (6 and 7) fed on diet containing $10 \%$ and $20 \%$ burger, respectively. Subgroups (8 and 9) fed on diet containing $10 \%$ and $20 \%$ meat loaves, respectively.
\end{abstract}

The positive control group induced defectiveness in all parameters. Feeding rats with diets containing the two levels from flaxseeds powder, row goat meat and goat meat products fortified with flaxseed powder led to significant decrease in serum cholesterol, triglycerides $(p<0.001)$, low density lipoprotein $(p<0.01)$, uric acid $(p<0.001)$, urea nitrogen $(p<0.001)$, creatinine $(p<0.001)$ and liver enzymes ASAT $(\mathrm{p}<0.001)$ and ALAT $(\mathrm{p}<0.001)$, while high density lipoprotein increased significantly $(\mathrm{p}<0.05)$ as compared to the positive control group.

Keywords: flaxseeds powder, row goat meat, goat meat products fortified with flaxseed powder, lipid profile, liver function and kidney function.

\section{Introduction}

American heart association (AHA) defined hyperlipidemia is a high level of fats in the blood. These fats, called lipids include cholesterol and triglycerides. There are different types of hyperlipidemia depending on which lipid levels are high in the blood (Jain et al., 2007). Elevated levels of plasma total cholesterol (TC), low-density lipoprotein cholesterol (LDL-C) and triacylglycerol
(TAG) as well as reduced levels of plasma high density lipoprotein cholesterol (HDL-C) are often associated with an increased risk of coronary heart disease (Smith et al., 2004). Hypercholesterolemia is a condition characterized by very high levels of cholesterol in the blood. (Adaramoye et al., 2008). Hypercholesterolemia is one of the most important risk factors for atherosclerosis and subsequent cardiovascular disease (Steinberg, 
2002). Feeding animals with cholesterol has often been used to elevate serum or tissue cholesterol levels to study the etiology of hypercholesterolemia-related metabolic disturbances (Bocan, 1998). Exogenous hypercholesterolemia causes fat deposition in the liver and depletion of the hepatocyte population; it can also cause malfunctioning of the liver, which apparently follows micro vesicular stenosis due to the intracellular accumulation of lipids (Assy et al., 2000). In addition, feeding cholesterol rich diets induces free radical production (ROS), followed by oxidative stress and hypercholesterolemia (Bulur et al., 1995).

During the past decades many studies have focused on improving lipid profiles (as one of the most important risk factors of chronic diseases) by planning a better diet or introducing herbal treatments. Thus, many plants were proposed to have health benefits in reducing blood lipid profile (Oplinger et al. 1989).

Flaxseed flour (FF) is ranked among the very important functional foods because of its very high content of alpha-linoloenic acid (ALA), dietary fiber, lignin, flavonoids, phenolics and good quality protein (Berglund, 2002). It is unique among oil seeds due to its high content of mucilage and gums in the outer layer of seeds and contains mainly xylose, rhamnose, galactose, glucose, arabinose, fucose and galacturonic acid (Chen et al., 2007). The whole seed and oil of flax had been used for edible purposes in some European and Asian countries. According to Daun et al. (2003), flaxseed oil usually contains greater than $50 \%$ of ALA. There is more information on the use of flaxseed in bakery products (Lipilina and Ganj, 2009) and meat products (Valencia et al., 2008). The water binding and emulsifying properties of flaxseed mucilage had contributed to its use in selected food systems (i.e fish sauce, ice-creams and meat emulsions) (Singer et al., 2011).

Nutritionally, goat is an important source of high quality proteins, healthy fats, and with low calorie, intramuscular fat, saturated fat, and sodium contents. Additionally, goat meat has high levels of iron, potassium and essential amino acids, which should range it within the category of high quality meat (Horcada et al., 2012). Meat from goats had gained acceptance mainly because of its lower fat content than beef and lamb meat. Therefore, it requires low-heat and slow cooking to preserve tenderness and juiciness (Madruga et al., 2008). On the other hand, the appearance, tenderness, flavor, and juiciness properties are important categories affecting goat meat acceptability (Dhanda et al., 1999 and Silva et al., 2011). This study was undertaken to determine if flaxseed powder, row goat meat and goat meat products fortified with flaxseed powder would alter the quantity of liver enzymes, lipid fraction and kidney function of rats suffering from hyperlipidemia.

\section{Materials and Methods}

\subsection{Materials}

- Chevon meat (rib cut and round cut) was obtained from Assiut slaughterhouse (1 year old) and stored at $4{ }^{\circ} \mathrm{C}$ until use

- linseed was obtained from agriculture researches center, dried at 
$170^{\circ}$ then, grinding as powder to fortified goat meat products.

- Commercial kits used for determination of TC (total cholesterol), TG (triglyceride), HDL-C (high density lipoprotein-cholesterol), ALT (alanine aminotransferase) AST (aspartate aminotransferase), Creatinine, Urea \& Uric Acid were purchased from AL-GOMHORIA COMPANY for diagnostic materials.

\subsection{Methods}

2.2.1. Preparation of meat products:

Four kilograms of meat was minced using a meat mincer. Four different formulations (burger $10 \%$, burger $20 \%$, meat loaves $10 \%$, and meat loaves $20 \%$ ) were prepared (Tables 1 and 2).

Table 1. Formulations of meat loaves (g)*.

\begin{tabular}{|c|c|c|}
\hline Ingredients & Meat loaves 10\% & Meat loaves 20\% \\
\hline Cheavon Meat & 695 & 595 \\
\hline Salt & 5 & 5 \\
\hline Black Pepper powder & 5 & 5 \\
\hline Nutmeg & 5 & 5 \\
\hline Parsley crunched & 15 & 50 \\
\hline Egg & 50 & 100 \\
\hline Canned Tomatoes & 100 & 25 \\
\hline Bread Crumbs & 25 & 200 \\
\hline Flax seeds powder & 100 & 2 \\
\hline
\end{tabular}

*(Saba, 2010)

Table 2. Formulations of burger (g)*.

\begin{tabular}{|c|c|c|}
\hline Ingredients & burger10\% & Burger 20\% \\
\hline Cheavon Meat & 790 & 690 \\
\hline egg & 50 & 50 \\
\hline Grated potatoes & 40 & 40 \\
\hline salt & 5 & 5 \\
\hline Nutmeg & 5 & 5 \\
\hline Onion powder & 5 & 5 \\
\hline Black Pepper powder & 5 & 5 \\
\hline Flax seeds powder & 100 & 200 \\
\hline
\end{tabular}

*(Saba, 2010)

\subsubsection{Biological Methods:}

The study included (60) Albino Rats, their weights range between $(100 \mathrm{~g}-120 \mathrm{~g})$. They were obtained from the animal house of the faculty of Medicine, Assiut University. The animals were housed as groups in wire cages under the normal laboratory conditions and were fed on basal diets for two weeks as adaptation period. Then the rats were fed for four weeks on treatment materials. The rats were divided into (10) groups, each group consisted of (6) rats. 
Group (1): the negative control group (feed on basal diet)

Group (2): the positive control group (feed on fat rich diet)

Group (3): feed on fat rich diet in addition to $10 \%$ powder of goat meat

Group (4): feed on fat rich diet in addition to $20 \%$ powder of goat meat

Group (5): feed on fat rich diet in addition to $10 \%$ powder of linseed

Group (6): feed on fat rich diet in addition to $20 \%$ powder of linseed

Group (7): feed on fat rich diet in addition to $10 \%$ powder of fortified burger with $10 \%$ powder of linseed

Group (8): feed on fat rich diet in addition to $10 \%$ powder of fortified burger with $20 \%$ powder of linseed

Group (9): feed on fat rich diet in addition to $10 \%$ powder of fortified meat loaves with $10 \%$ powder of linseed

Group (10): feed on fat rich diet in addition to $10 \%$ powder of fortified meat loaves with $20 \%$ powder of linseed

Table 3. Ingredients of basal diet

\begin{tabular}{|l|c|}
\hline Ingredients & Percentage \\
\hline Corn starch & $67.8 \%$ \\
\hline Casein & $12.5 \%$ \\
\hline Corn oil & $10 \%$ \\
\hline mixture of vitamins & $1 \%$ \\
\hline mixture of salt & $3.5 \%$ \\
\hline Choline Chloride & $0.2 \%$ \\
\hline Cellulose & $5 \%$ \\
\hline
\end{tabular}

*(AIN) American Institute of Nutrition.

\subsubsection{Preparation of Biotical Samples}

After the end of experiments, the blood samples were collected into centrifuge tube. The collected blood was placed 30-40 min for clot formation, and then the serum was separated by centrifugation at $3000 \mathrm{rpm}$ for $15 \mathrm{~min}$. Then the serum frozen at $-20 \mathrm{C}$ for analysis.

\subsubsection{Measurement of Bio-} chemical

Serum total cholesterol level, serum triglycerides level, serum HDL-c and serum LDL-cholesterol level, were determined according to the method described by Artiss \& Zak (1997), Cole et al. (1997), Lopes-Virella et al. (1977) and Wieland \& Seidel (1983) respectively. While, serum alanine aminotransferases (ALAT) and aspartate aminotransferases (ASAT) activities were determined according to the method described by Schumann and Klauke, (2003) serum creatinine activity, serum urea activity were determined according to the method described by Young (2001) and serum uric acid level were determined according to the method described by Barham and Trinder (1972).

\subsubsection{Statistics:}

All data were expressed as Means \pm SD. Groups of data were compared with t-test, values of $\mathrm{P}<$ $0.05, \mathrm{P}<0.01$ and $\mathrm{P}<0.001$ were regarded as significant.

\section{Results and Discussion}

3.1. Serum Cholesterol, Triglyceride, HDL\&LDL (mg/dL):

Tables (4\&5) and figures (1-4) shows the mean values of total cholesterol, triglycerides, HDL and LDLcholesterol in serum rats. All treatments groups of flaxseed, row goat meat and goat meat products fortified with flaxseed powder compared to the positive control group. The data 
showed significant decrease in total cholesterol level in treatment groups; row meat $10 \%$, row meat $20 \%$, flaxseed $10 \%$, flaxseed $20 \%$, burger $10 \%$, burger $20 \%$, meat loaves $10 \%$ and meat loaves $20 \%$ by $27.1,19.2,21.5$, $46.5,36.3,25.52,41.2$ and $22.4 \%$ respectively. A similar effect has been observed in case of triglycerides. The data showed significant decrease in total triglycerides level in treatment groups; row meat $10 \%$, row meat $20 \%$, flaxseed $10 \%$, flaxseed $20 \%$, burger $10 \%$, burger $20 \%$, meat loaves $10 \%$ and meat loaves $20 \%$ by $27.2,21.7,18.3,26.3,35.2,31.8,31.6$ and $36.8 \%$ respectively. While HDLcholesterol showed insignificant increase by all treatments of flaxseed, row goat meat and goat meat products fortified with flaxseed powder. Except in the case of $20 \%$ burger was low significant. On the other hand LDL-cholesterol showed significant decrease in all treatment groups; row meat $10 \%$, row meat $20 \%$, flaxseed $10 \%$, flaxseed $20 \%$, burger $10 \%$, burger $20 \%$, meat loaves $10 \%$ and meat loaves $20 \%$ by $8.5,13.6,12.6$, $11.6,9.2,8.3,11.1$ and $9.9 \%$ respectively.

Flaxseed has approximately $57 \%$ ALA in $100 \mathrm{~g}$ of oil (BarcelóCoblijn \& Murphy, 2009) and is one of the richest sources of ALA. Eicosapentaenoic acid (EPA) and docosahexaenoic acid (DHA), which are converted from ALA in the body, have anti-inflammatory factor and have effect on reducing the risk of many chronic diseases like atherosclerosis, cardiovascular disease (CVD), cancer and hyperlipidemia (Zhang, et al. 2008; Simopoulos, 2002). Although in literature the con- version efficacy of ALA to EPA and DHA is mentioned to be below $0.6 \%$ in animal models ( $\mathrm{Su}$, et al. 2001), many literatures have related the hypocholesterolemic effect of flaxseed to high ALA content of flaxseed oil (Vijaimohan, et al. 2006; Riediger et al. 2008). Flaxseed is also the richest source of Secoisolariciresinoldiglucoside (SDG), approximately $1 \%$ of flaxseed dry weight is SDG (Meagher $\&$ Beecher, 2000). Literatures also suggest that flaxseed lignans have blood lipid profiles improving effects (Zhang, et al. 2007). Lignans are estrogen like components which also have antioxidant activity in reducing the oxidative damage in many diseases like heart disease, cancer and diabetes (Vanharanta, et al. 2003; Prasad, 2000; Prasad, 2001). Besides, the high fiber content of flaxseed (approximately $27 \mathrm{~g}$ fiber per $100 \mathrm{~g}$ ) can also contribute to the hypocholesterolemic effect of flaxseed. Two mechanisms for the effect of dietary fiber are proposed. First that dietary fiber can reduce oxidation of glucose and lipids, besides it can provide a healthy intestinal environment. Another mechanism is that dietary fiber can reduce inflammation by changing adipocytokines in adipose tissue and reducing blood cholesterol by interrupting enterohepatic circulation of cholesterol or by fat binding properties (King, 2005). Many studies unanimously addressed different sources of fiber as cholesterol lowering and lipid profile improving factor (Li, et al. 2003). Therefore the lipid profile improving effect of flaxseed can be mostly due to the existence of high level of ALA, lignans and fiber in flaxseed. Thus by increasing the 
dosage of flaxseed in diet the blood lipid profile improving effect of flaxseed increases. Prasad (1997) concluded that the reduction in hypercholesterolemic atherosclerosis by flaxseed is due to a decrease in serum total cholesterol and LDL cholesterol. Also, they indicated that the antiatherogenic activity of flaxseed is independent of its $\alpha$-linolenic acid content. Mandasescu et al. (2005) inves- tigated the effect of daily consumption of dietary flaxseed (as a source of linolenic acid, LNA) on plasma lipid concentrations in mildly hyperlipidemic patients, and reported that flaxseed supplementation was associated with significant reductions in TC $(-17.2 \%), \quad$ LDL-C $(-3.9 \%), \quad$ TG $(36.3 \%)$ and TC/HDL-C ratio ($33.5 \%)$.

Table 4. Mean values of serum Cholesterol, Triglycerides, HDL\&LDL of normal diet, high fat diet and high fat diet animal groups treated with flaxseed, row goat meat and goat meat products.

\begin{tabular}{|c|c|c|c|c|c|}
\hline \multicolumn{2}{|c|}{ Groups $\quad$ Parameters } & Cholesterol & HDL & LDL & Triglyceride \\
\hline Gp 1 & $\mathrm{M} \pm \mathrm{SD}$ & $96.3 \pm 4.6$ & $30.3 \pm 2.00$ & $50.3 \pm 2.00$ & $112.9 \pm 6.1$ \\
\hline Gp 2 & $\mathrm{M} \pm \mathrm{SD}$ & $166.9 \pm 7.7$ & $25.4 \pm 1.9$ & $58.8 \pm 2.3$ & $180.00 \pm 2.3$ \\
\hline Gp 3 & $\mathrm{M} \pm \mathrm{SD}$ & $121.6 \pm 5$ & $27.6 \pm 1.1$ & $53.8 \pm 1.00$ & $131.1 \pm 6.6$ \\
\hline Gp 4 & $\mathrm{M} \pm \mathrm{SD}$ & $134.9 \pm 10.8$ & $27.6 \pm 1.7$ & $50.8 \pm 2.3$ & $140.9 \pm 6.00$ \\
\hline Gp 5 & $\mathrm{M} \pm \mathrm{SD}$ & $131 \pm 15.2$ & $26.9 \pm 1.9$ & $51.4 \pm 3.7$ & $147 \pm 11.3$ \\
\hline Gp 6 & $\mathrm{M} \pm \mathrm{SD}$ & $89.3 \pm 8.9$ & $28.1 \pm 2.5$ & $52.00 \pm 2.3$ & $132.6 \pm 7.5$ \\
\hline Gp 7 & $\mathrm{M} \pm \mathrm{SD}$ & $106.4 \pm 8.8$ & $27.00 \pm 2.2$ & $53.4 \pm 2.5$ & $116.6 \pm 5.2$ \\
\hline Gp 8 & $\mathrm{M} \pm \mathrm{SD}$ & $124.3 \pm 11.8$ & $28.4 \pm 1.4$ & $53.9 \pm 0.6$ & $122.7 \pm 6.3$ \\
\hline Gp 9 & $\mathrm{M} \pm \mathrm{SD}$ & $98.1 \pm 10.6$ & $27.1 \pm 0.4$ & $52.3 \pm 1.9$ & $123.2 \pm 5.8$ \\
\hline Gp 10 & $\mathrm{M} \pm \mathrm{SD}$ & $129.5 \pm 6.8$ & $27.00 \pm 1.3$ & $53.00 \pm 2.7$ & $113.8 \pm 7.7$ \\
\hline
\end{tabular}

Table 5. Students t-test values for cholesterol, triglyceride, LDL and HDL in the serum of male Albino rats.

\begin{tabular}{|c|c|c|c|c|}
\hline Groups & Parameters & HDL & LDL & Triglyceride \\
\hline Gp2\& Gp3 & Cholesterol & & & \\
\hline Gp2\& Gp4 & $5.754^{* * *}$ & $1.824 \mathrm{NS}$ & $4.575^{* *}$ & $21.007^{* * *}$ \\
\hline Gp2\& Gp5 & $5.191^{* *}$ & $2.228 \mathrm{NS}$ & $4.922^{* *}$ & $15.266^{* * *}$ \\
\hline Gp2\& Gp6 & $22.775^{* * *}$ & $1.029 \mathrm{NS}$ & $4.231^{* *}$ & $6.432^{* * *}$ \\
\hline Gp2\& Gp7 & $23.844^{* * *}$ & $2.478 \mathrm{NS}$ & $3.874^{* *}$ & $15.196^{* * *}$ \\
\hline Gp2\& Gp8 & $10.385^{* * *}$ & $3.281^{*}$ & $3.181^{* *}$ & $29.651^{* * *}$ \\
\hline Gp2\& Gp9 & $10.129^{* * *}$ & $2.160 \mathrm{NS}$ & $4.881^{* *}$ & $23.091^{* * *}$ \\
\hline Gp2\& Gp10 & $11.294^{* * *}$ & $1.396 \mathrm{NS}$ & $5.320^{* *}$ & $23.851^{* * *}$ \\
\hline
\end{tabular}

*: low significance $(\mathrm{P}<0.05)$ **: highly significance $(\mathrm{P}<0.01)$.

$* * *$ : highly highly significance $(\mathrm{P}<0.001)$. N.S: non significance $(\mathrm{P}>0.05)$. 


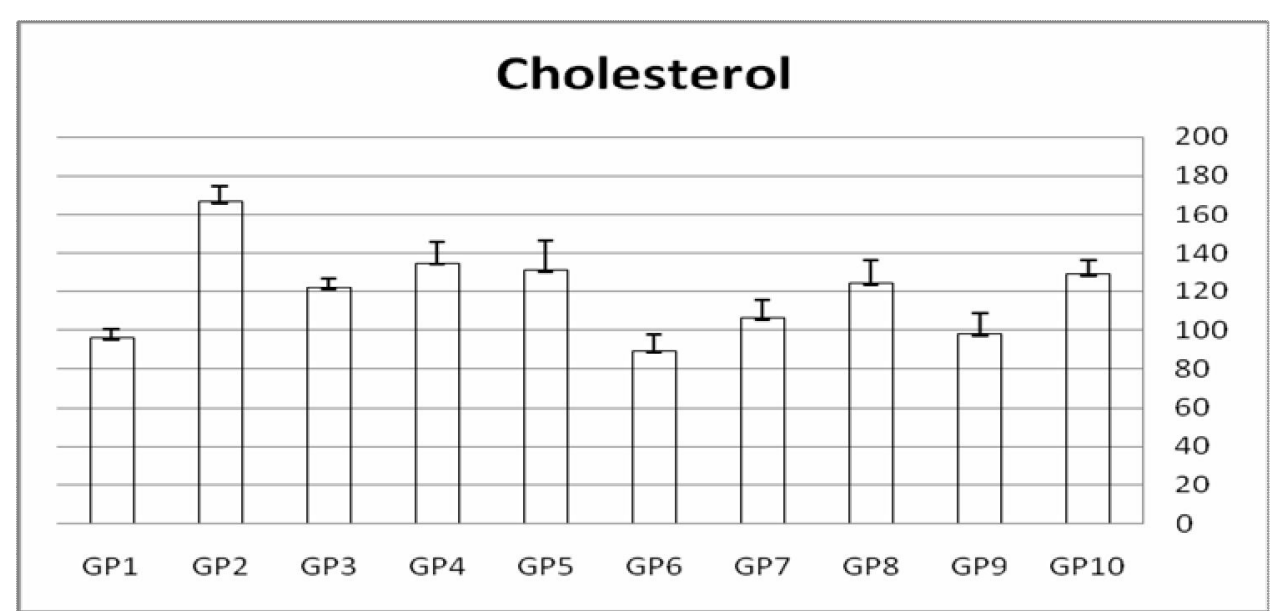

Figure 1. Mean values of serum cholesterol of herbal treated and high fat diet animal groups comparing with control groups.

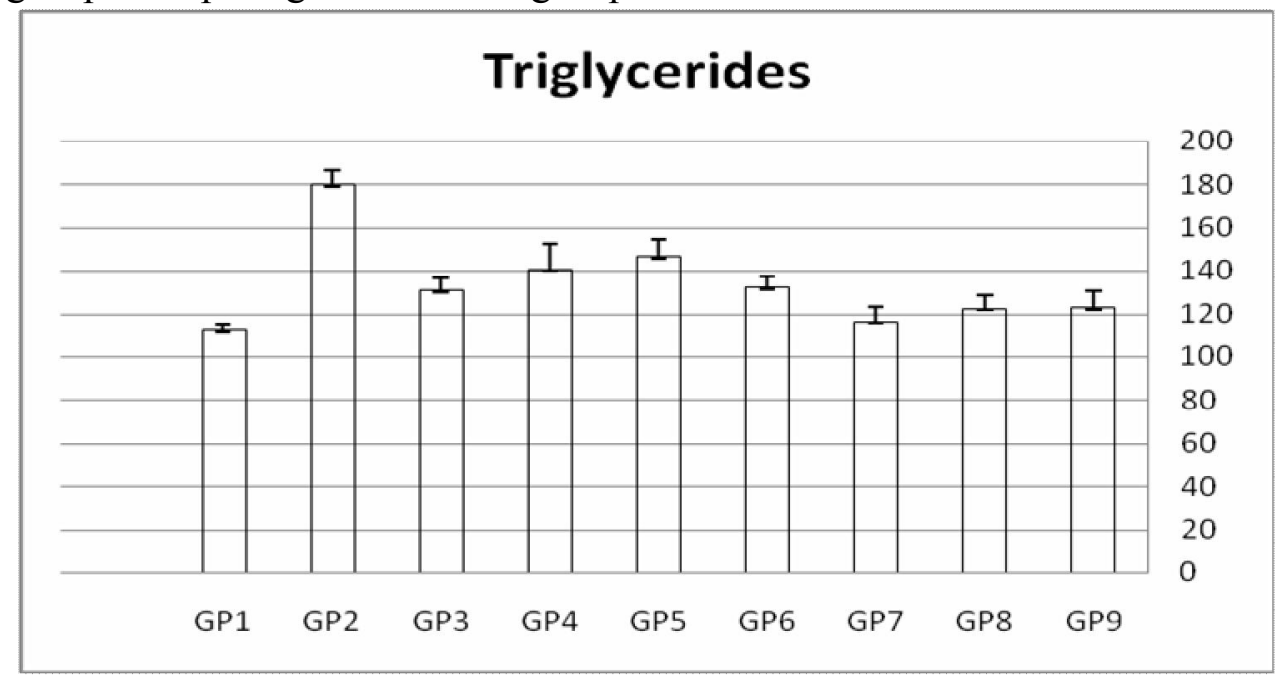

Figure 2. Mean values of serum Triglyceride of herbal treated and high fat diet animal groups comparing with control groups.

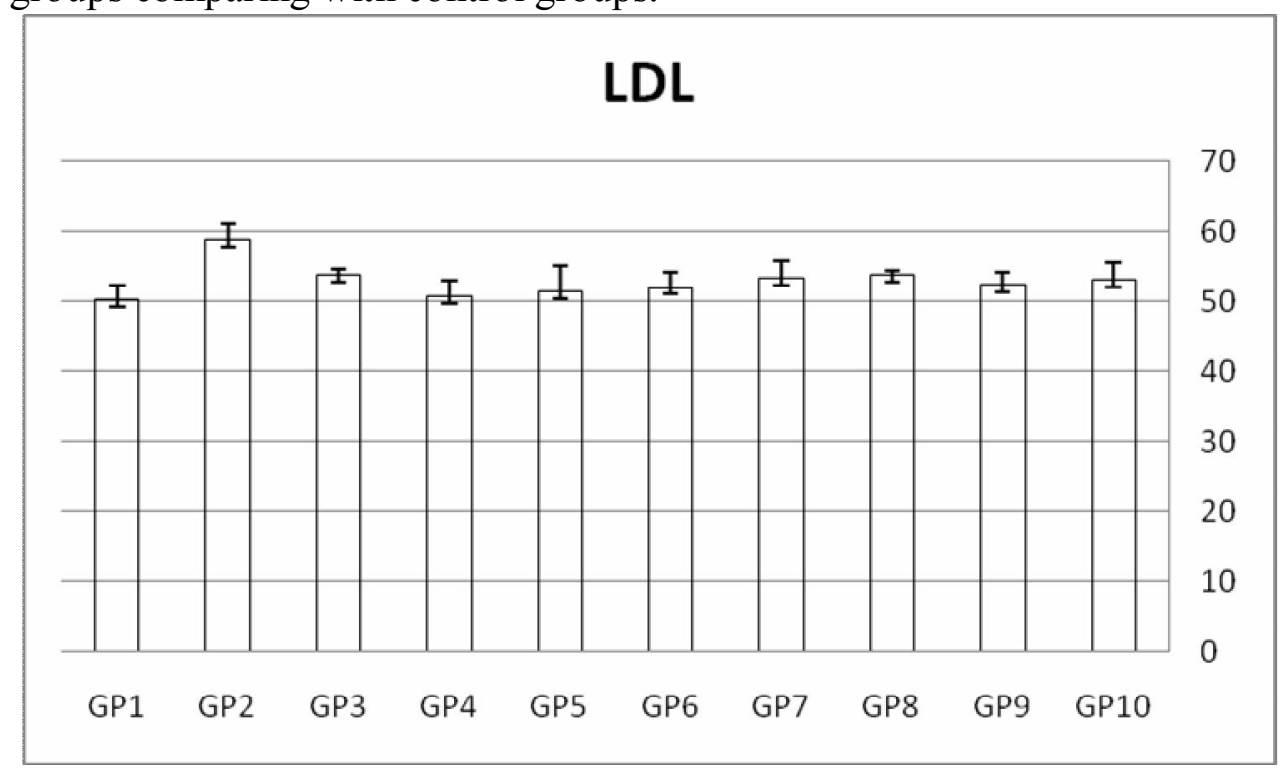

Figure 3. Mean values of serum LDL-Cholesterol of herbal treated and high fat diet animal groups comparing with control groups. 


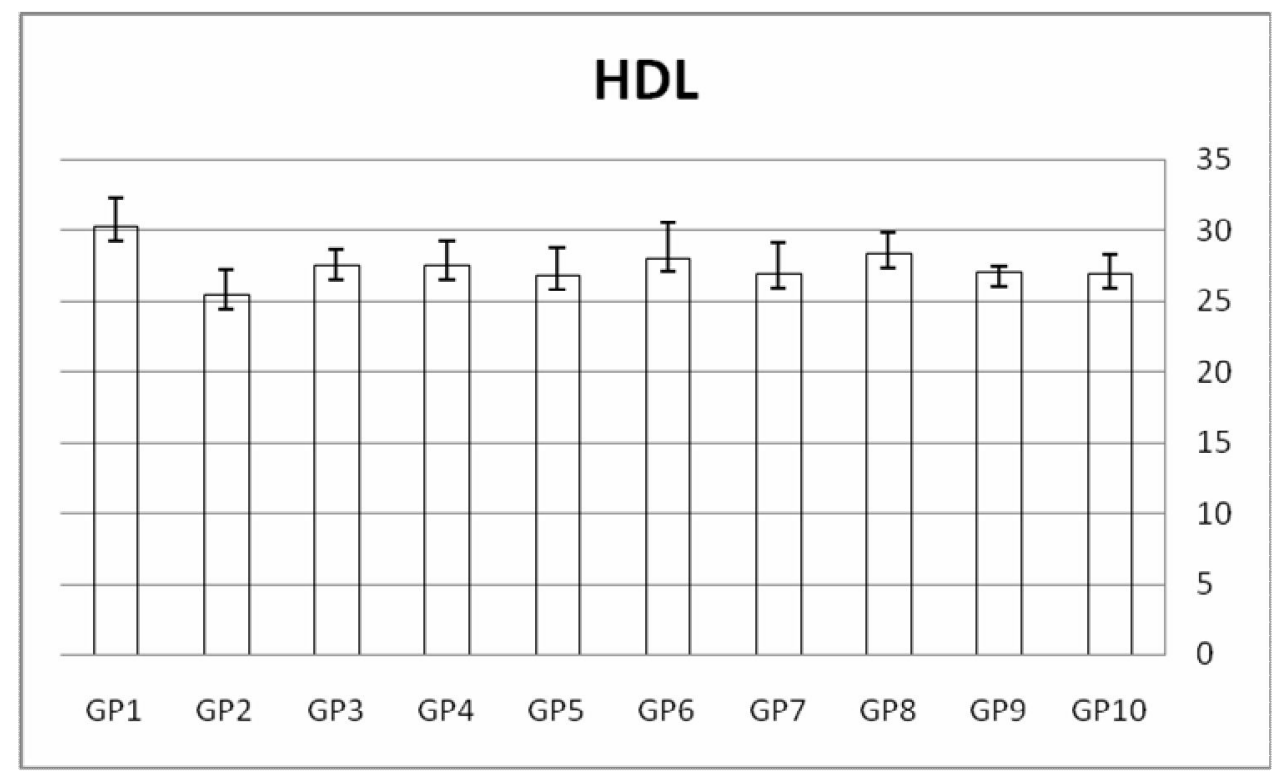

Figure 4. Mean values of serum HDL-Cholesterol of herbal treated and high fat diet animal groups comparing with control groups.

\subsection{Serum Creatinine, Urea \& Uric Acid (mg/dl):}

Tables (6\&7) and figures (5, 6 and $7)$ shows the mean values of creatinine, urea, and uric acid in serum of male Wistar albino rats (Rattus norvegicus). All treatments groups of flaxseed, row goat meat and goat meat products fortified with flaxseed powder compared to the positive control group. The data showed highly highly significant decrease in creatinine level in treatment groups; row meat $10 \%$, row meat $20 \%$, flaxseed $10 \%$, flaxseed $20 \%$, burger $10 \%$, burger $20 \%$, meat loaves $10 \%$ and meat loaves $20 \%$ by $31.8,22.7,31.8$, $40.9,36.4,36.4,27.3$ and $27.3 \%$ respectively. A similar effect has been observed in case of urea. The data showed highly highly significant decrease in urea level in treatment groups; row meat $10 \%$, row meat $20 \%$, flaxseed $10 \%$, flaxseed $20 \%$, burger $10 \%$, burger $20 \%$, meat loaves $10 \%$ and meat loaves $20 \%$ by $40.9,37.8,47.4,55.5,46.8,34.3,38.5$ and $34.2 \%$ respectively. Also, a similar effect has been observed in case of uric acid. The data showed highly highly significant decrease in uric acid level in treatment groups; row meat $10 \%$, row meat $20 \%$, flaxseed $10 \%$, flaxseed $20 \%$, burger $10 \%$, burger $20 \%$, meat loaves $10 \%$ and meat loaves $20 \%$ by $31,33.8$, $45.1,32.4,33.8,28.2,31$ and $26.8 \%$ respectively.

Clark et al, (1995) demonstrated that flaxseed consumption decline significantly serum creatinine with 30 and $45 \mathrm{~g}$. There was a concomitant increase in creatinine clearance with increasing flaxseed dose. Proteinuria was reduced with $30 \mathrm{~g}$ and to a lesser extent with $45 \mathrm{~g}$ of flaxseed. In conclusion, $30 \mathrm{~g}$ flaxseed/day was well tolerated and conferred benefit in terms of renal function as well as inflammatory and atherogenic mechanisms important in the pathogenesis of lupus nephritis. Abdel-Moneim et al. (2011) suggested that administration of flaxseed oil decreased the levels of serum creatinine, blood urea nitrogen and uric acid. 
Table 6. Mean values of serum creatinine, urea $\&$ uric acid of normal diet, high fat diet and high fat diet animal groups treated with flaxseed and goat meat products.

\begin{tabular}{|c|c|c|c|c|}
\hline \multicolumn{2}{|c|}{ Parameters } & Creatinine & Urea & Uric Acid \\
\hline Groups & $\mathrm{M} \pm \mathrm{SD}$ & $1.2 \pm 0.07$ & $41.3 \pm 1.9$ & $4.6 \pm 0.3$ \\
\hline $\mathrm{Gp} 1$ & $\mathrm{M} \pm \mathrm{SD}$ & $2.2 \pm 0.09$ & $106.3 \pm 4.5$ & $7.1 \pm 0.3$ \\
\hline $\mathrm{Gp}$ 3 3 & $\mathrm{M} \pm \mathrm{SD}$ & $1.5 \pm 0.1$ & $62.8 \pm 5.9$ & $4.9 \pm 0.4$ \\
\hline $\mathrm{Gp} 4$ & $\mathrm{M} \pm \mathrm{SD}$ & $1.7 \pm 0.09$ & $66.1 \pm 5.9$ & $4.7 \pm 0.3$ \\
\hline $\mathrm{Gp} 5$ & $\mathrm{M} \pm \mathrm{SD}$ & $1.5 \pm 0.1$ & $55.9 \pm 5.2$ & $3.9 \pm 0.3$ \\
\hline $\mathrm{Gp} 6$ & $\mathrm{M} \pm \mathrm{SD}$ & $1.3 \pm 0.07$ & $47.3 \pm 3.9$ & $4.8 \pm 0.8$ \\
\hline Gp 7 & $\mathrm{M} \pm \mathrm{SD}$ & $1.4 \pm 0.1$ & $56.5 \pm 8.2$ & $4.7 \pm 0.7$ \\
\hline Gp 8 & $\mathrm{M} \pm \mathrm{SD}$ & $1.4 \pm 0.1$ & $68.8 \pm 2.1$ & $5.1 \pm 0.5$ \\
\hline Gp 9 & $\mathrm{M} \pm \mathrm{SD}$ & $1.6 \pm 0.07$ & $65.4 \pm 8.1$ & $4.9 \pm 0.4$ \\
\hline Gp 10 & $\mathrm{M} \pm \mathrm{SD}$ & $1.6 \pm 0.09$ & $69.9 \pm 5.8$ & $5.2 \pm 0.5$ \\
\hline
\end{tabular}

Table 7. Students t-test values for creatinine, urea and uric acid in the serum of male Albino rats.

\begin{tabular}{|c|c|c|c|}
\hline Groups & Creatinine & Urea & Uric Acid \\
\hline Gp2\& Gp3 & $14.128^{* * *}$ & $16.270^{* * *}$ & $10.185^{* * *}$ \\
\hline Gp2\& Gp4 & $7.196^{* * *}$ & $12.369^{* * *}$ & $11.319^{* * *}$ \\
\hline Gp2\& Gp5 & $12.384^{* * *}$ & $18.060^{* * *}$ & $20.154^{* * *}$ \\
\hline Gp2\& Gp6 & $16.453^{* * *}$ & $26.166^{* * *}$ & $7.106^{* * *}$ \\
\hline Gp2\& Gp7 & $12.374^{* * *}$ & $13.080^{* * *}$ & $8.661^{* * *}$ \\
\hline Gp2\& Gp8 & $8.909^{* * *}$ & $22.115^{* * *}$ & $8.814^{* * *}$ \\
\hline Gp2\& Gp9 & $15.209^{* * *}$ & $11.507^{* * *}$ & $13.054^{* * *}$ \\
\hline Gp2\& Gp10 & $9.209^{* * *}$ & $8.978^{* * *}$ & $8.211^{* * *}$ \\
\hline
\end{tabular}

*: low significance $(\mathrm{P}<0.05){ }^{* *}$ : highly significance $(\mathrm{P}<0.01)$.

$* * *$ : highly highly significance $(\mathrm{P}<0.001)$.N.S: non significance $(\mathrm{P}>0.05)$.

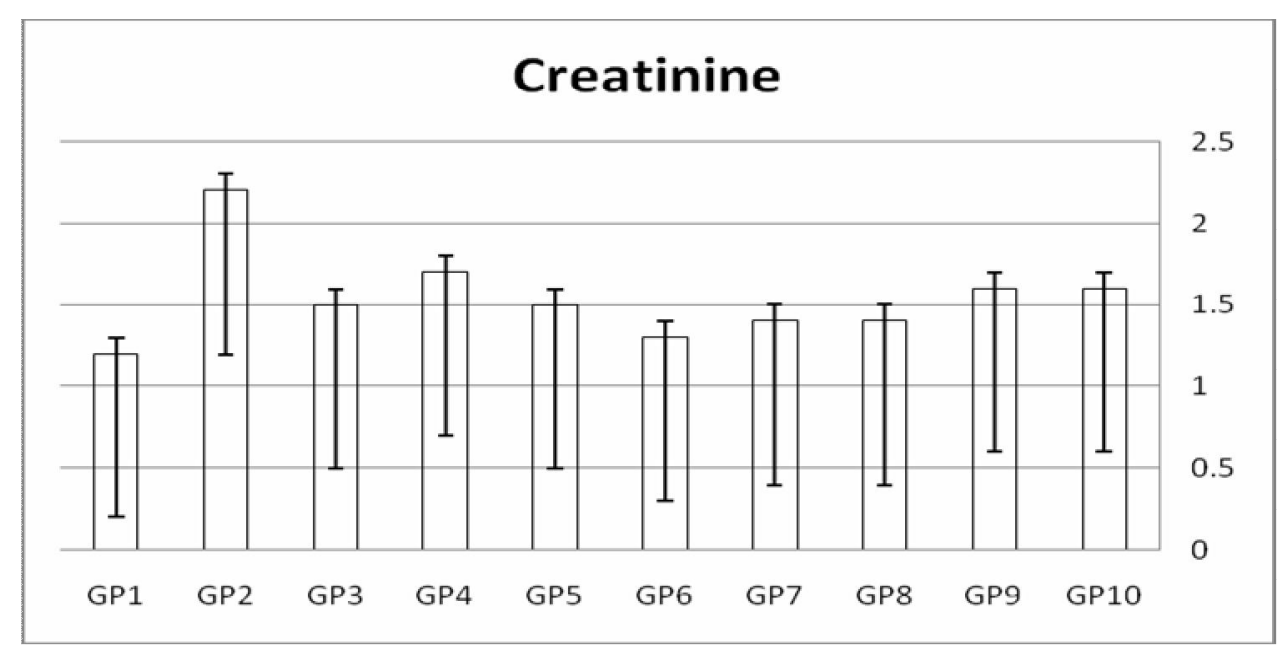

Figure 5. Mean values of serum Creatinin of herbal treated and high fat diet animal groups comparing with positive control groups. 


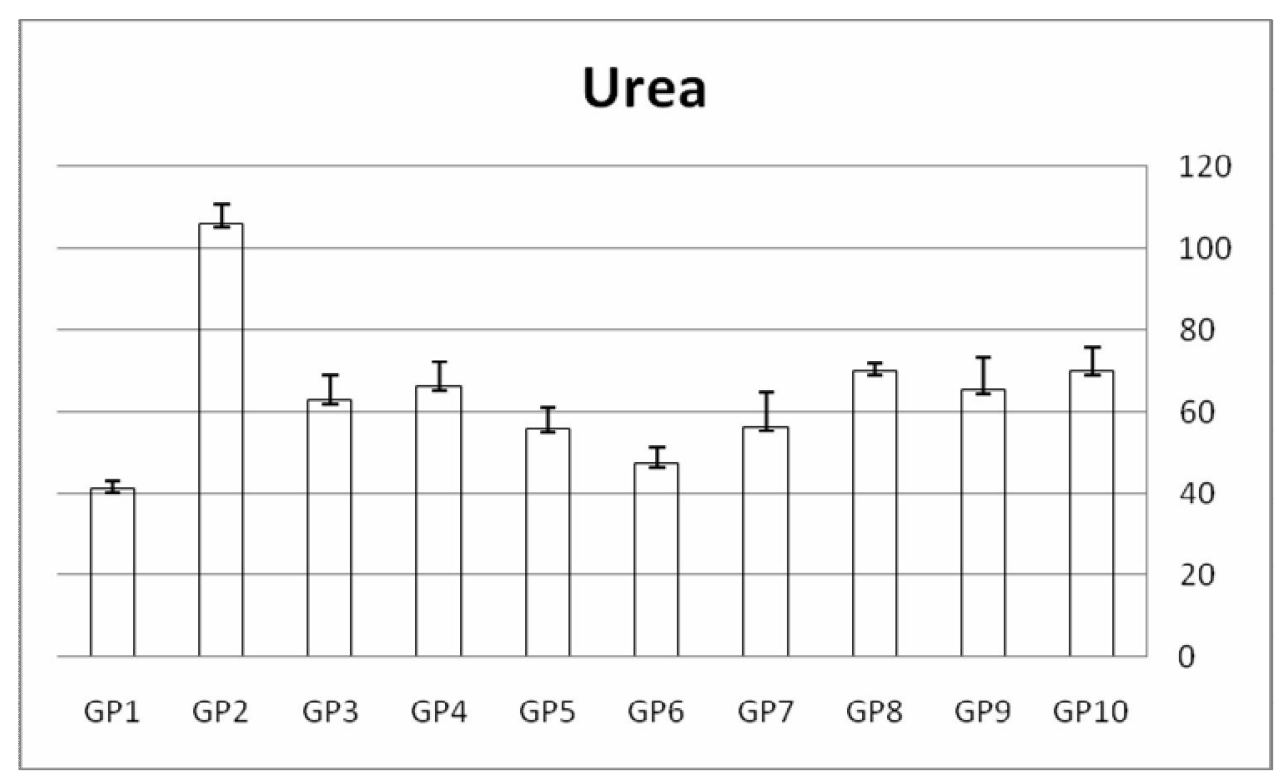

Figure 6. Mean values of serum Urea of herbal treated and high fat diet animal groups comparing with positive control groups.

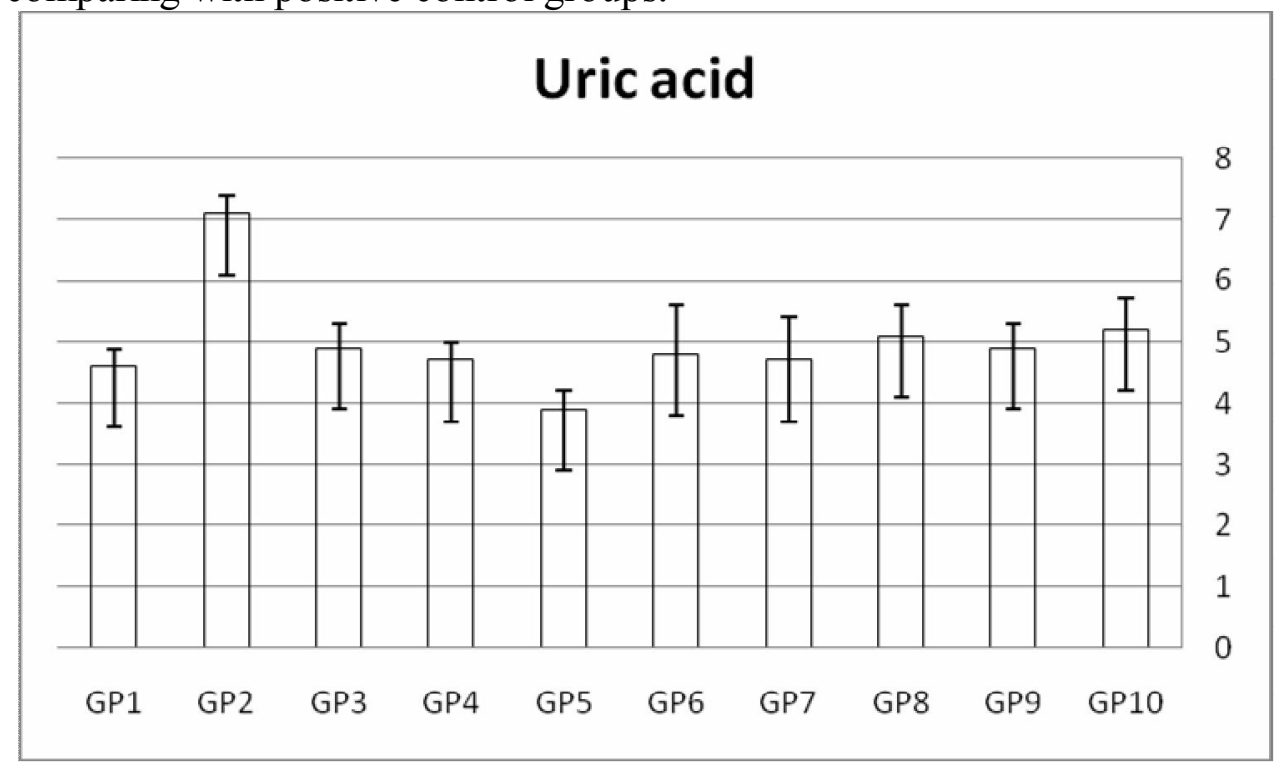

Figure 7. Mean values of serum Uric Acid of herbal treated and high fat diet animal groups comparing with positive control groups.

3.3. Serum alanine aminotransferase (ALAT) and Aspartate aminotransferases (ASAT) activities (IU/l):

Tables (8 and 9) and figures (8\&9) shows the mean values of ALAT and ASAT activities in serum of male Wistar albino rats (Rattus norvegicus). All treatments groups of flaxseed, row goat meat and goat meat products fortified with flaxseed powder compared to the positive control group. The data showed highly highly significant decrease in ALAT level in treatment groups; row meat $10 \%$, row meat $20 \%$, flaxseed $10 \%$, flaxseed $20 \%$, burger $10 \%$, burger $20 \%$, meat loaves $10 \%$ and meat loaves $20 \%$ by $35.8,31.3,32.7,28.8,22.3,32.5,36.8$ 
and $29.8 \%$ respectively. A similar effect has been observed in case of ASAT. The data showed highly highly significant decrease in ASAT level in treatment groups; row meat $10 \%$, row meat $20 \%$, flaxseed $10 \%$, flaxseed $20 \%$, burger $10 \%$, burger $20 \%$, meat loaves $10 \%$ and meat loaves $20 \%$ by $32.3,34.2,34.5$, $32.8,26.4,32.3,38$ and $32.9 \%$ respectively.

Hemmings and Song (2005) mentioned that flaxseed consumption conferred greated protection against liver injury in the males than in the females which suggests an involvement of the estrogenic lignan component of flaxseed. This hepatoprotection is through a flax lignan-induced increase in reduced glutathione related to a flax effect on the activity of liver gamma GT in the resting state and the maintenance of its activity in response to injury. Abdel-Wahab and Aly (2005) observed that treatment with clove and cardamom effectively decreased liver enzyme levels in the serum. This can be attributed to the presence of antioxidant in clove and cardamom which contain phenolic compounds that can act by scavenging free radicals. Faseehuddin Shakir and Madhusudhan (2007) Suggested that, the activities of serum marker enzymes glutamate ox- aloacetate transminase (GOT), glutamate pyruvate transaminase (GPT) and alkaline phosphatase (ALP) were elevated significantly in carbon tetrachloride induced rats. Administration of flaxseed chutney $(15 \%, \mathrm{w} / \mathrm{w})$ resulted in depletion of serum marker enzymes and exhibited recoupment thus showing significant hepatoprotective effect. It was observed that flaxseed chutney supplemented diet could lower the serum cholesterol and as a potential source of antioxidants it could exert protectionagainst hepatotoxic damage induced by carbon tetrachloride (CCl4) in rats. Sadeek and Abd El-Razek (2010) reported that serum AST, ALT, ALP, total bilirubin were significantly lower $(\mathrm{p}<0.05)$ after five weeks intake of $2 \%$ clove and $2 \%$ cardamom in iron overloaded rats.

\section{Conclusion}

Flaxseed powder resulted in improvement of shelf-life of industrial meat products because it contains antioxidants and polyphenols. In addition to, improvement of organic and sensor peculiarities for meat products and consumer acceptance, flaxseed has an effective role in reducing cholesterol levels and its fractions.

Table 8. Mean values of serum ALAT and ASAT activity of normal diet, high fatty diet and high fatty diet animal groups treated with flaxseed and goat meat products.

\begin{tabular}{|c|c|c|c|}
\hline \multicolumn{2}{|c|}{$\begin{array}{ll}\text { Groups } & \text { Parameters } \\
\end{array}$} & \multirow{2}{*}{$\begin{array}{c}\text { ALAT IU/L } \\
33.6 \pm 3.6\end{array}$} & \multirow{2}{*}{$\begin{array}{c}\text { ASAT IU/L } \\
38.9 \pm 1.9\end{array}$} \\
\hline Gp 1 & $\mathrm{M} \pm \mathrm{SD}$ & & \\
\hline Gp 2 & $\mathrm{M} \pm \mathrm{SD}$ & $60.00 \pm 2.7$ & $70.8 \pm 3.2$ \\
\hline Gp 3 & $\mathrm{M} \pm \mathrm{SD}$ & $38.5 \pm 2.5$ & $47.9 \pm 1.2$ \\
\hline Gp 4 & $\mathrm{M} \pm \mathrm{SD}$ & $41.2 \pm 2.9$ & $46.6 \pm 5 \cdot 1$ \\
\hline Gp 5 & $\mathrm{M} \pm \mathrm{SD}$ & $40.4 \pm 3.7$ & $46.4 \pm 4.9$ \\
\hline Gp 6 & $\mathrm{M} \pm \mathrm{SD}$ & $42.7 \pm 2.3$ & $47.6 \pm 3.5$ \\
\hline Gp 7 & $\mathrm{M} \pm \mathrm{SD}$ & $46.6 \pm 4.1$ & $52.1 \pm 5.1$ \\
\hline Gp 8 & $\mathrm{M} \pm \mathrm{SD}$ & $40.5 \pm 1.2$ & $47.9 \pm 5.9$ \\
\hline Gp 9 & $\mathrm{M} \pm \mathrm{SD}$ & $37.9 \pm 1.5$ & $43.9 \pm 3.4$ \\
\hline Gp 10 & $\mathrm{M} \pm \mathrm{SD}$ & $42.1 \pm 2.4$ & $47.5 \pm 3.9$ \\
\hline
\end{tabular}


Table 9. Students t-test values for ALAT and ALST in the serum of male Albino rats.

\begin{tabular}{|c|c|c|}
\hline Groups & ALAT IU/L & ASAT IU/L \\
\hline Gp2\& Gp3 & & $18.311^{* * *}$ \\
\hline Gp2\& Gp4 & $15.755^{* * *}$ & $9.079^{* * *}$ \\
\hline Gp2\& Gp5 & $12.763^{* * *}$ & $18.203^{* * *}$ \\
\hline Gp2\& Gp6 & $11.456^{* * *}$ & $19.669^{* * *}$ \\
\hline Gp2\& Gp7 & $9.842^{* * *}$ & $17.388^{* * *}$ \\
\hline Gp2\& Gp8 & $7.262^{* * *}$ & $7.842^{* * *}$ \\
\hline Gp2\& Gp9 & $23.296^{* * *}$ & $11.612^{* * *}$ \\
\hline Gp2\& Gp10 & $16.264^{* * *}$ & $9.183^{* * *}$ \\
\hline
\end{tabular}

*: low significance $(\mathrm{P}<0.05)$. $\quad * *$ : highly significance $(\mathrm{P}<0.01)$.

$* * *$ : highly highly significance $(\mathrm{P}<0.001)$. N.S: non significance $(\mathrm{P}>0.05)$.

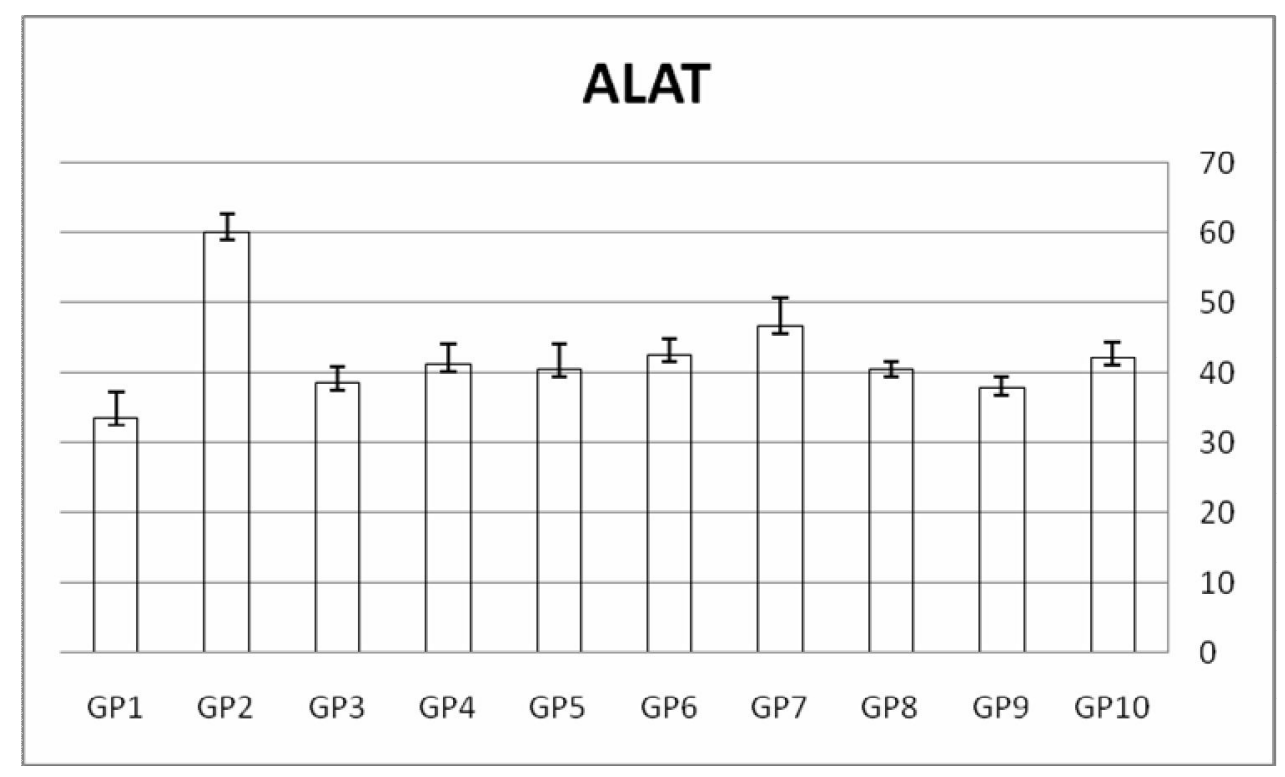

Figure 8. Mean values of serum ALAT activity of herbal treated and high fatty diet animal groups comparing with positive control groups. 


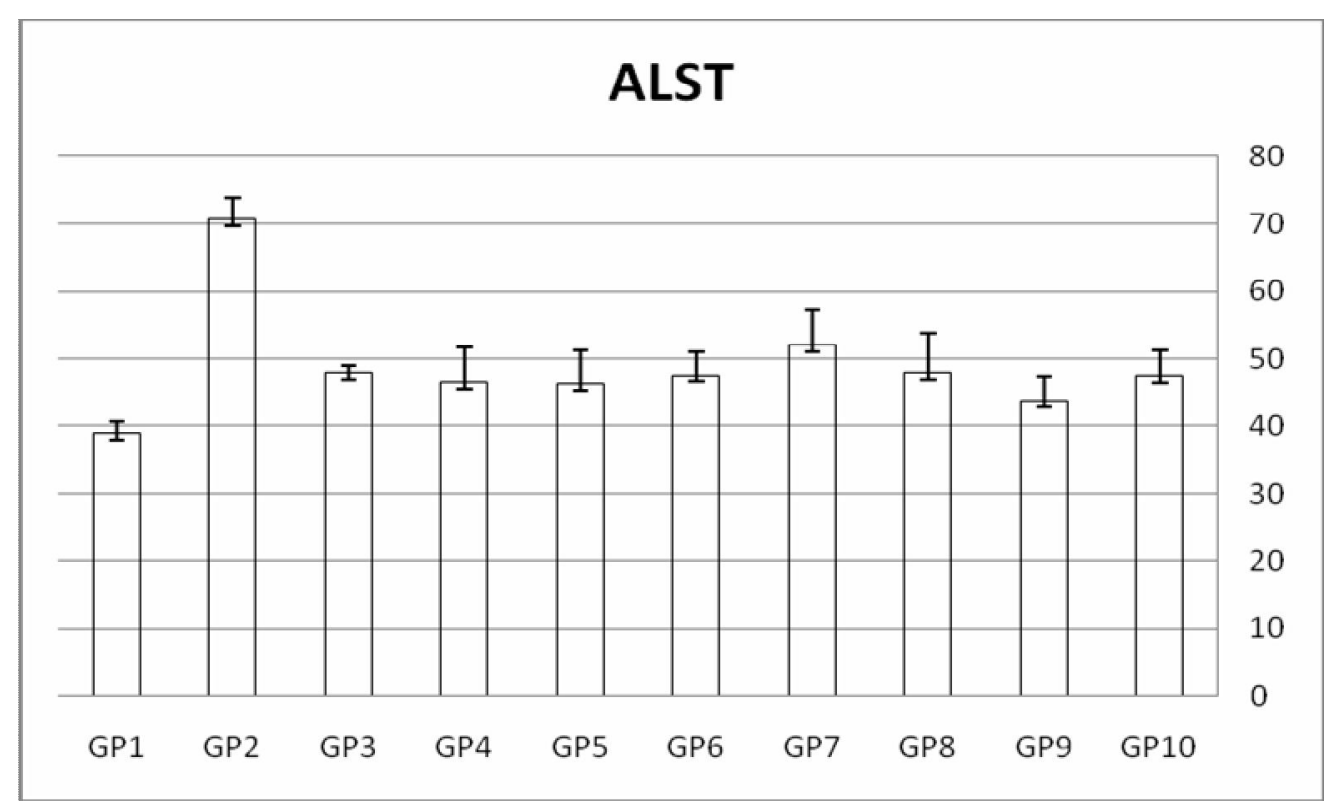

Figure 9. Mean values of serum ALST activity of herbal treated and high fatty diet animal groups comparing with positive control groups.

\section{References}

Abdel-Moneim, A.E.; Dkhill, M.A. and Al-Quraishy, S. (2011). The potential role of flaxseed oil on lead acetate induced kidney injure in adult male albino rats. Afr. J. Biotechnol., 10(8):1436-1451.

Abdel-Wahab, M. and Aly, S. (2005). Antioxidant property of Nigella sativa (black curcumin) and Syzygium aromaticum (clove) in rats during aflatoxicosis. J. Appl. Toxicol., 25(3):218-23.

Adaramoye, O.A., Akintayo, O., Achem, J., Fafunso, M.A. (2008). Lipidlowering effects of methanolic extract of vernonia amygdalina leaves in rats fed on high cholesterol diet. Vascular health and Risk Management. 4: 235-241.

Artiss, J.D. and Zak, B. (1997). Measurement of cholesterol concentration. In: Rifai, N.; Warnick, G. R. and Dominiczak, M. H., (Eds.), Handbook of lipoprotein testing, pp. 99-114.

Assy, N., Kaita, K., Mymin, D., Levy, C., Rosser, B., Minuk, G. (2000). Fatty infiltration of liver in hyper- lipidemic patients. Dig. Dis. Sci. 45: 1929-1934.

Barceló-Coblijn G, \& Murphy E (2009). Alpha-linolenic acid and its conversion to longer chain n-3 fatty acids: Benefits for human health and a role in maintaining tissue n-3 fatty acid levels. Progress in Lipid Research; 48(6), 355-374.

Barham, D. and Trinder, P. (1972). Determination of uric acid using enzymatic colorimetric method. Analyst, 97:142.

Berglund, D. R. (2002). Flax: new uses and demands. Trends in new crop and new uses, ASHS press, Alexandria, VA. pp. 358-360.

Bocan, T.M. (1998). Animal models of atherosclerosis and interpretation of drug intervention studies. Curr. Pharm. Des. 4: 37-52.

Bulur, H., Ozdemirler, G., Oz, B., Toker, G., Ozturk, M., Uysal, M. (1995). High cholesterol diet supplemented with sunflower seed oil but not olive oil stimulates lipid peroxidation in plasma, liver, and aorta of rats. J. Nut. Biochem. 6: $547-550$. 
Chen, H. H., S. Xui, and Z. Wang. (2007). Interaction between flaxseed gum and meat protein. J. Food Eng. 80:1051-1059.

Clark, W.F.; Parbtani, A.; Huff, M.W.; Spanner, E.; de Salis, H.; ChinYee, I.; Philbrick, D. J. and Holub, B.J. (1995). Flaxseed: a potential treatment for lupus nephritis. Kidney Int., 48 (2):475-80.

Cole, T. G.; Klotzsch, S. G. and McNamara, J. (1997). Measurement of triglyceride concentration. In: Rifai, N.; Warnick, G. R. and Dominiczak, M. H., (Eds.), Handbook of lipoprotein testing. Washington: AACC Press, pp. 115-126.

Daun, J. K., V. J. Barthet, T.L. Chornick, and S. Duguid. (2003). Structure, composition, and variety development of flaxseed. In: Flaxseed in Human Nutrition (Ed. L. U. Thompson, and S. C.Cunnane). AOCS Press, Champaign, USA, pp. 1-40.

Dhanda, J.S., D.G. Taylor, P.J. Murray and J.E. McCosker, (1999). The influence of goat genotype on the production of Capretto and Chevon carcasses. 2. Meat quality. Meat Sci., 52: 363-367.

Faseehuddin Shakir, K.A. and Madhusudhan, B. (2007). Hypocholesterolemic and hepatoprotective effects of flaxseed Chutney: evidence from animal studies. Ind. J Clin. Biochem., 22 (1) 117-121.

Hemmings, S.F. and Song, X. (2005). The effects of dietary flaxseed on the Fischer 344 rat. III. Protection against CCl4-induced liver injury. Cell Biochem. Funct., 23(6):38998.

Horcada, A., G. Ripoll, M.J. Alcalde, C. Sañudo, A. Teixeira, B. Panea, (2012). Fatty acid profile of three adipose depots in seven Spanish breeds of suckling kids. Meat Sci., 92: 89-96.
Jain, K.S., Kathivarin, M.K., Rahul, S., chamanal J. (2007). The biology and chemistry of hyperlipidemia. Bioorganic and Medicinal Chemistry.15: 4674-4699.

King, D. (2005). Dietary fiber, inflammation, and cardiovascular disease. Molecular nutrition \& food research; 49(6), 594-600.

Li J, Kaneko T, Qin L, Wang J, Wang Y, \& Sato A. (2003) Long-term effects of high dietary fiber intake on glucose tolerance and lipid metabolism in GK rats: comparison among barley, rice, and cornstarch. Metabolism; 52(9), 1206-1210.

Lipillina, E. and V. Ganj. (2009). Incorporation of ground flaxseed in bakery products and its effect on sensory and nutritional characteristics-a pilot study. J. Food Sci.20:50-59.

Lopes-Virella, M.F.; Stone, P.; Ellis, S. and Colwell, J.A. (1977). Cholesterol etermination in high-denisty lipoproteins separated by three different methods. Clin. Chem. 23: 882-884. systems. RevistaBrasileira de Zootecnia, 38(3): 547-552.

Madruga, M.S., T.S. Torres, F.F. Carvalho, R.C. Queiroga, N. Narain and D. Garruti, (2008). Meat quality of Moxotó and Canindé goats as affected by two levles of feeding. Meat Sci., 80: 1019-1023.

Mandasescu, S.; Mocain, V.; Dascalita, A.M.; Haliga, R.; Nestian, I.; Still, P.A. and Luca, V. (2005). Flaxseed supplementation in hyperlipidemic patients. Rev Med.Chir. Soc.Med. Nat. Tasi., 109(3):502-6.

Meagher L, \& Beecher G. (2000). Assessment of data on the lignan content of foods. Journal of food composition and analysis; 13(6), 935947.

Oplinger, E., Oelke, E., Doll, J., Brundy, L., Schuler, R. (1989). Flax. Alternative Field Manual. University of 
Winsconsin-Extension corporative extension St.Paul.USA, 114-126.

Prasad, K. (1997). Dietary flaxseed in prevention of hypercholesterolemic atherosclerosis. Mol. Cell Biochem., 132(1): 6976.

Prasad K.(2000). Flaxseed: a source of hypocholesterolemic and antiatherogenic agents. Drug News Perspect; 13(2), 99-104.

Prasad K. (2001). Secoisolariciresinol diglucoside from flaxseed delays the development of type 2 diabetes in Zucker rat. Journal of laboratory and clinical medicine; 138(1), 3239.

Riediger N, Othman R, Fitz E, Pierce G, Suh M, \& Moghadasian M. (2008). Low n-6: n-3 fatty acid ratio, with fish-or flaxseed oil, in a high fat diet improves plasma lipids and beneficially alters tissue fatty acid composition in mice. European journal of nutrition; 47(3), 153160.

Saba, n (2010). Cooking: science and art. DAR AL-MAAREF.11:213-344.

Sadeek, E.A. and Abd El-Razek, F.H. (2010). The chemo-protective effect of turmeric, Chili, cloves and cardamom on correcting iron overload-induced liver injury, oxidative stress and serum lipid profile in rat models. J. Am. Sci., 6(10):702712 .

Schumann, G. and Klauke, R. (2003). New IFCC reference pr ocedures for the determination of catalytic activity concentrations of five enzymes in serum: preliminary upper reference limits obtained in hospitalized subjects,. Clin. Chim. Acta. 327: 69-79.

Silva, T.M., R.L. Oliveira, L.P. Larissa Pires Barbosa, A.F. GarcezNeto, A.R. Bagaldo, D.P. Duarte Lanna, M.C.Alves da Silva and I. Brito de Jesus, (2011). Preliminary Study on Meat Quality of Goats Fed Levels of Licury Oil in the Diet. Asian-Aust. J. Anim. Sci., 24(8): 1112-1119.

Simopoulos A.(2002). The importance of the ratio of omega-6/omega-3 essential fatty acids. Biomedecine \& Pharmacotherapy; 56(8), 365379.

Singer, F. A. W., F. S. Taha, S. S. Mohamed, A. Gibriel, and M. ENawawy. (2011).Preparation of protein/mucilage products from flaxseed. Am. J. Food.Tech. 6:260278.

Smith, J.S.C., Jackson, R., Pearson, T.A., Fuster, V., Yusuf, S., Faergeman, O.,Wood, D.A., Alderman, M., Horgan, J., Home, P., Hunn, M., Grundy, S.M.(2004). Principles for national and regional guidelines on cardiovascular disease prevention: a scientific statement from the World Heart and Stroke Forum. Circulation. 109: 3112-3121.

Steinberg, D. (2002). Atherogenesis in perspective: hypercholestero-lemia and inflammation as partners in crime. Nat.Med. 8: 1211-1217.

Su H, Huang M, Saad N, Nathanielsz P, \& Brenna J.( 2001). Fetal baboons convert 18: $3 n-3$ to $22: 6 n-3$ in vivo: a stable isotope tracer study. Journal of Lipid Research; 42(4), 581.

Valencia, I., M. N. O'Grady, D. Ansorena, I. Astiasaran, and J. P. Kerry. (2008). Enhancement of the nutritional status and quality of fresh pork sausages following the addition of linseed oil, fish oil and natural antioxidants. Meat Sci. 80:1046-1054.

Vanharanta M, Voutilainen S, Rissanen T, Adlercreutz H, \& Salonen J.( 2003). Risk of cardiovascular disease-related and all-cause death according to serum concentrations 
of enterolactone: Kuopio Ischaemic Heart Disease Risk Factor Study. Archives of internal medicine; 163(9), 1099.

Vijaimohan K, Jainu M, Sabitha K, Subramaniyam S, Anandhan C, \& Shyamala Devi C. (2006). Beneficial effects of alpha linolenic acid rich flaxseed oil on growth performance and hepatic cholesterol metabolism in high fat diet fed rats. Life sciences; 79(5), 448-454.

Wieland, U.D. and Seidel, J. (1983). A simple specific method for precipitation of low density lipoproteins. Lipid Res. 24: 904-909.
Young, D.S. (2001). Effects of disease on Clinical Lab. Tests, 4th ed AACC.

Zhang $\mathrm{W}$, Wang $\mathrm{X}$, Liu $\mathrm{Y}$, Tian $\mathrm{H}$, Flickinger B, Empie M.W, and Sun S.Z (2007). Dietary flaxseed lignan extract lowers plasma cholesterol and glucose concentrations in hypercholesterolaemic subjects. British Journal of Nutrition; 99 (06), 1301-1309.

Zhang W, Wang $\mathrm{X}$, Liu $\mathrm{Y}$, Tian $\mathrm{H}$. Flickinger B, Empie M.W and Sun S.Z (2008). Effects of dietary flaxseed lignan extract on symptoms of benign prostatic hyperplasia. Journal of medicinal food; 11(2), 207-214. 
تاثير منتجات لحوم الماعز المدعمه بدقيق الكتان على مكونات الدهون ووظائف الكبل والكلى لذكور فئران الالبينو

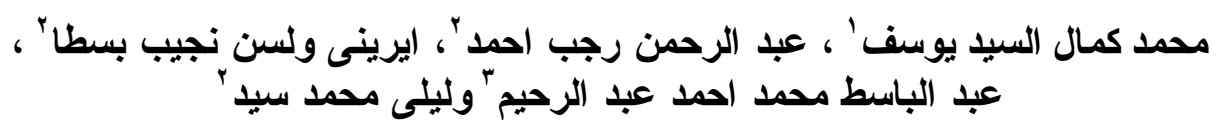

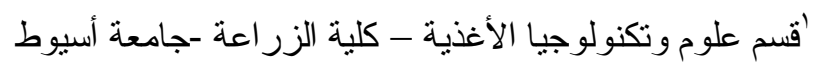

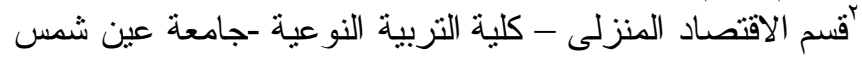

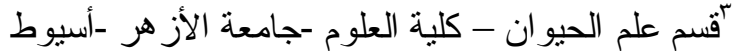

(الملخص

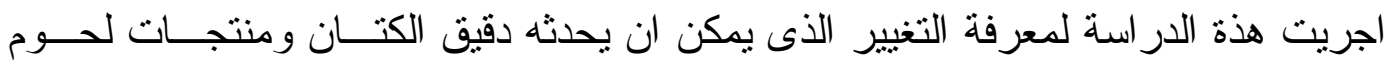

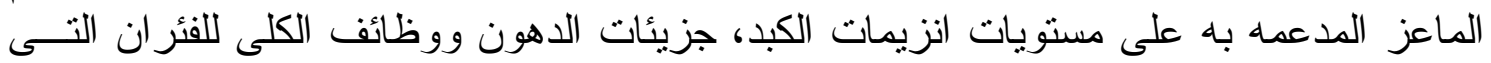

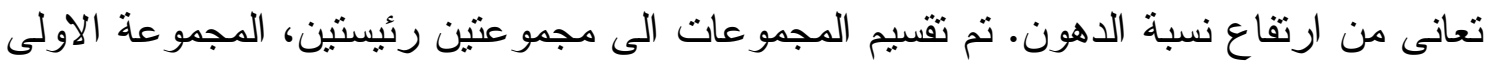

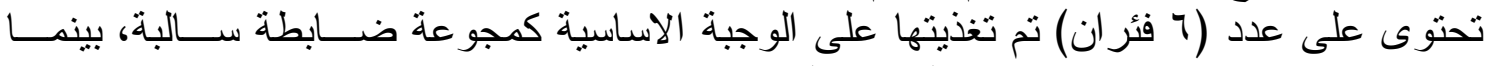

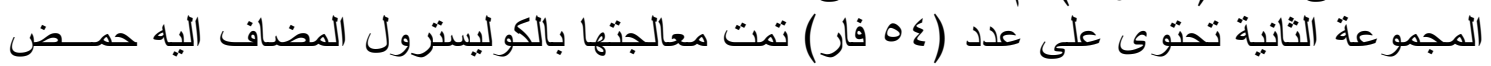

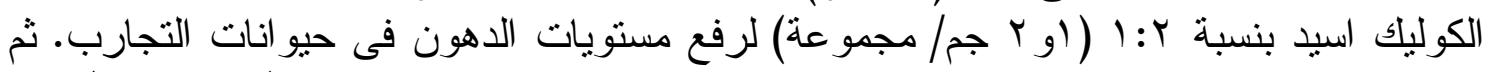

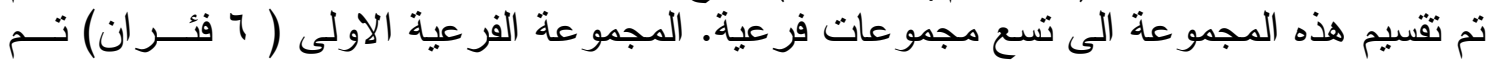

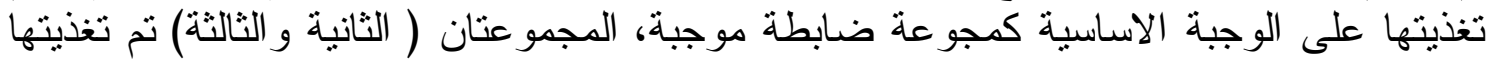

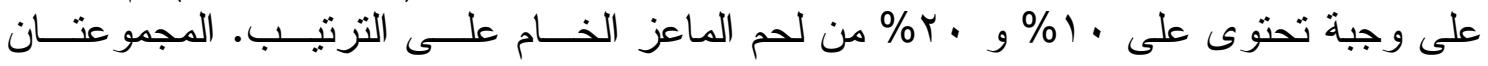

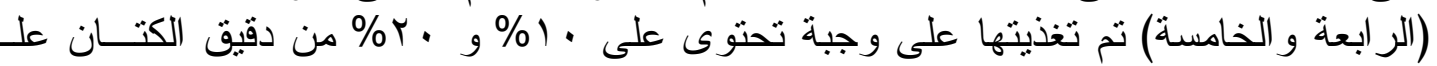

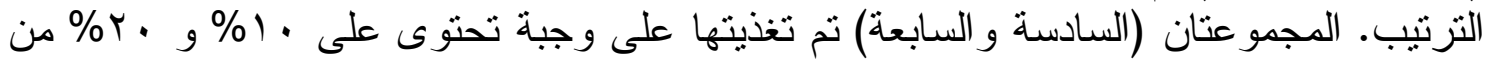

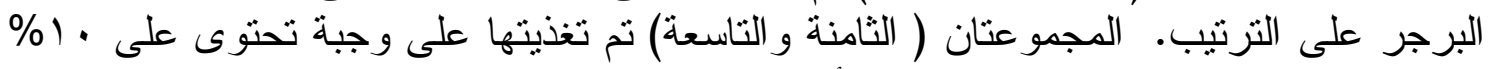

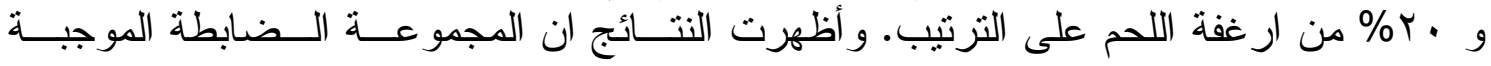

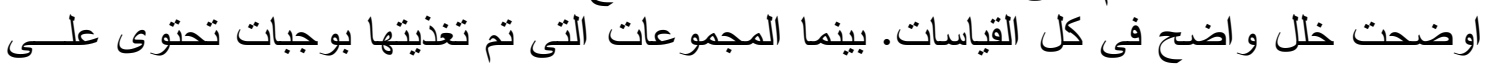

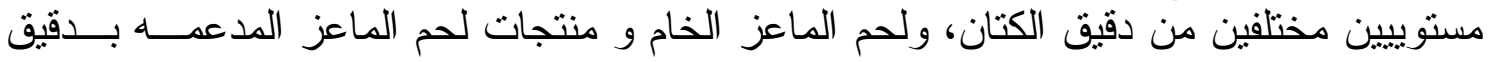

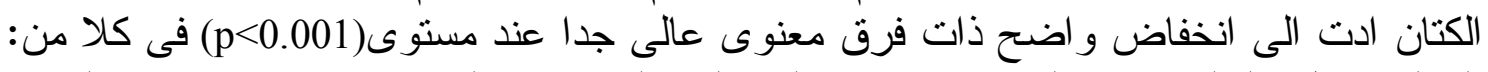

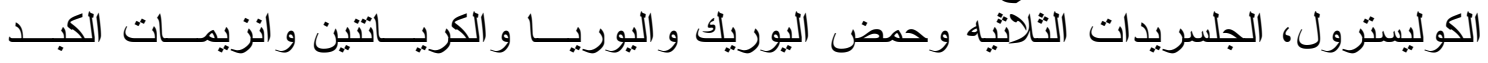

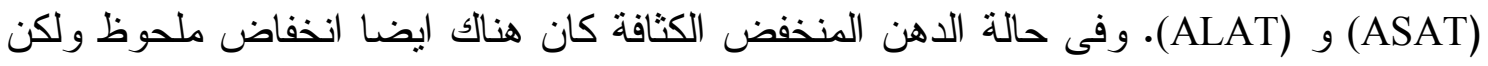

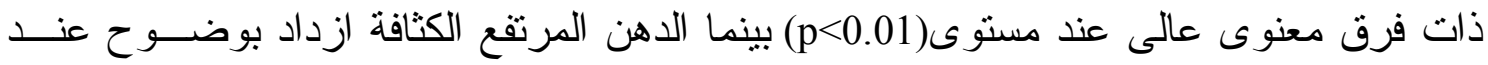
فرق معنوى (p<0.005) وذلك عند عند مقارنته بالمجمو عة الضابطة الموجبة. 